\title{
Evaluation of an electronic cowside test to detect subclinical ketosis in dairy cows
}

\author{
M. Iwersen, U. Falkenberg, R. Voigtsberger, D. Forderung, and W. Heuwieser ${ }^{1,2}$ \\ Clinic for Animal Reproduction, Faculty of Veterinary Medicine, Free University of Berlin, 14163 Berlin, Germany
}

\begin{abstract}
The objective of this study was to determine the diagnostic performance of an electronic $\beta$-hydroxybutyrate (BHBA) hand-held meter (Precision Xtra) for use in dairy cattle. Specific objectives were to compare the electronic BHBA meter with serum BHBA concentrations determined photometrically and 2 commonly used chemical cowside tests (Ketostix, Ketolac) and to evaluate accuracy in a field study employing 35 investigators. Of the 196 blood samples collected in experiment 1, 17 (8.7\%) contained $\geq 1,200 \mu \mathrm{mol}$ of BHBA/L of blood and $10(5.1 \%)$ contained $\geq 1,400 \mu \mathrm{mol}$ of BHBA/L of blood. Pearson correlation coefficients were highly significant for all tests. The highest correlation coefficient (0.95) was found between measurements of whole blood BHBA determined with the Precision Xtra test and the serum BHBA concentrations determined photometrically. Correlation coefficients between serum BHBA and BHBA in urine using Precision Xtra and Ketostix, and milk using Ketolac were lower. The Precision Xtra test was both $100 \%$ sensitive and specific at $\geq 1,400 \mu \mathrm{mol}$ of $\mathrm{BHBA} / \mathrm{L}$ of whole blood. Using milk and urine, positive and negative predictive values were considerably lower for both chemical tests as well as for the electronic meter. In the second study undertaken with 35 bovine veterinary practices, 926 blood samples were collected. In this study, the Precision Xtra test had sensitivities of 88 and $96 \%$ at 1,200 and 1,400 $\mu \mathrm{mol}$ of BHBA/L of whole blood, respectively. Specificities were 96 and $97 \%$, respectively. Level of agreement was lower in the second study employing multiple investigators. Considerable differences in variance occurred among investigators. We conclude that the electronic hand-held BHBA measuring system using whole blood is a useful and practical tool to diagnose subclinical ketosis. Sensitivity and specificity are excellent for a
\end{abstract}

Received October 8, 2008.

Accepted January 21, 2009.

${ }^{1}$ Corresponding author: wolfgang.heuwieser@ubc.ca

${ }^{2}$ Current address: Animal Welfare Program, Faculty of Land and Food Systems, The University of British Columbia, Vancouver, BC, V6T 1Z4, Canada. cowside test and higher than 2 commonly used chemical dipsticks (Ketostix and Ketolac).

Key words: subclinical ketosis, $\beta$-hydroxybutyrate, diagnostic test, whole blood

\section{INTRODUCTION}

Subclinical ketosis is defined as elevated concentrations of circulating ketone bodies in the absence of clinical signs (Andersson, 1988). A threshold value of 1,400 $\mu \mathrm{mol} / \mathrm{L}$ BHBA of blood has been described to distinguish between cows with and without subclinical ketosis (Duffield, 1997; Geishauser et al., 2001; Oetzel, 2004). Subclinical ketosis can cause economic losses through decreased milk production, impaired reproductive performance, increased risk of displaced abomasums, and higher risk of clinical ketosis. The gold standard diagnostic test for subclinical ketosis is the measurement of BHBA in serum or plasma (Duffield, 2000). Serum BHBA measurement is useful for examining individual cows and evaluating herd health and monitoring feeding management practices. However, the quantitative determination of BHBA depends on special laboratory equipment and requires blood sampling, centrifugation, freezing of plasma or serum samples, and shipping of frozen materials to the laboratory. Useful guidelines have been recommended to assure optimal results when investigating herds for problems associated with subclinical ketosis (Stokol and Nydam, 2005). Several rapid cowside tests have been developed to alleviate these inconveniences, to reduce laboratory costs, and to provide results immediately after sampling (i.e., cowside).

Several cowside diagnostic tests (dipsticks, powders, tablets) for ketosis are commercially available. These are designed to detect acetoacetate, and to a lesser degree acetone, in urine (e.g., Ketostix strip, Bayer, Leverkusen, Germany) or BHBA in milk (e.g., Ketolac, Biolab, München, Germany) based on the degree of color change. The tests can be used semiquantitatively because the color change is more intense in the presence of higher levels of ketone bodies. Detailed comparisons of available cowside tests have been reviewed elsewhere (Geishauser et al., 1998, 2000; Carrier et al., 2004). 
Test characteristics of those cowside tests vary from test to test and from study to study. There is agreement that cowside tests are useful tools for diagnosing individual cases of subclinical ketosis and monitoring herd health. However, costs, inadequate sensitivities for milk tests, suboptimal specificities for urine tests, and the requirement for urine sampling have been described as drawbacks (Carrier et al., 2004). Also, testing for high SCC before milk testing is advisable because high SCC may cause false-positive results (Jeppesen et al., 2006).

In human medicine, electronic hand-held blood glucose and ketone measuring systems are widely used for diabetes monitoring (Guerci et al., 2005). A first report using an electronic human BHBA meter (MediSense Precision, Abbott, Abingdon, UK) for dairy cows described a high correlation $\left(\mathrm{r}^{2}=0.99\right)$ with BHBA concentrations determined spectrophotometrically (gold standard) and considered the test suitable for detecting subclinical ketosis in dairy cows (Jeppesen et al., 2006). Other studies used the same meter to monitor efficacy of glucogenic precursors in preventing subclinical ketosis in 45 beef cows (Endecott et al., 2004) or to describe the prevalence of subclinical ketosis on large dairies in Peru (Bryk-Lucy et al., 2008). None of the studies, however, revealed any data on test characteristics.

The objective of this study was to determine the diagnostic performance of an electronic BHBA measuring system (Precision Xtra, Abbott Diabetes Care, Abingdon, UK) for use in dairy cattle. Specific objectives were 2-fold: 1) to compare the electronic BHBA sensor with serum BHBA testing as the gold standard and with 2 commonly used chemical cowside tests (Ketostix and Ketolac); and 2) to evaluate accuracy of the Precision Xtra test in a field study employing a large number of investigators.

\section{MATERIALS AND METHODS}

Two experiments were conducted between May and July 2007 (experiment 1) and between January and April 2008 (experiment 2). An electronic BHBA measuring system was used for both experiments according to the label descriptions of the manufacturer. The system consists of a hand-held meter and electrochemical test strips. After the test strip has been inserted into the meter, blood is applied to the sample chamber. The BHBA in the sample is oxidized to acetoacetate in the presence of hydroxybuturate dehydrogenase with the concomitant reduction of $\mathrm{NAD}^{+}$to $\mathrm{NADH}$. The NADH is reoxidized to $\mathrm{NAD}^{+}$by a redox mediator. The current generated is directly proportional to the BHBA concentration in the sample. After $10 \mathrm{~s}$, the concentration of BHBA is displayed on the meter $(\mathrm{mmol} / \mathrm{L})$.
In experiment 1, 2 commercial dairy farms were used as research sites with approximately 1,200 Holstein cows at each farm. Cows were housed in free stall barns with rubber mats and slotted floors. Approximately $7 \mathrm{~d}$ before expected calving, cows were moved to free stall barns with straw bedding. Herd average milk yield for the 2 farms was 10,200 and 10,400 kg per lactation. A total of 196 dairy cows between 4 and $40 \mathrm{~d}$ after calving were enrolled in the study. Individual blood, milk, and urine samples were collected within an interval of up to $15 \mathrm{~min}$. For some cows, urine $(\mathrm{n}=10$; $5.1 \%)$ and milk $(\mathrm{n}=2 ; 1.0 \%)$ samples could not be collected. Blood samples were drawn from the coccygeal vein and/or artery with vacuum tubes (Venoject II, Terumo Europe NV, Leuven, Belgium). Milk samples were collected from one quarter and urine samples from the urine stream after massage of the region underneath the vulva. Whole blood was transferred to the sensor of the test strip (Precision Xtra $\beta$-ketone, Abbott Diabetes Care) by dipping the sensor directly onto the surface of the blood-filled tube immediately after collection. The values displayed on the hand-held meter were recorded onto a data capture form. Also, concentrations of BHBA in milk and urine were determined both with the electronic system and semiquantitatively with a chemical test (Ketostix and Ketolac, respectively). Blood samples were centrifuged (10 min, $\left.4^{\circ} \mathrm{C}, 1,000 \times g\right)$ and serum was stored in 2 aliquots at $-25^{\circ} \mathrm{C}$ until analysis. $\beta$-Hydroxybutyrate concentrations were measured using colorimetric enzymatic reactions (Ranbut D-3-hydroxybutyrate kit, Randox Laboratories, Antrim, UK) with an automated wet chemistry analyzer (Olympus AU 400, Olympus, Hamburg, Germany). The laboratory was previously validated using the University of Guelph (Pearson correlation $\mathrm{r}=0.91$, $\mathrm{n}=200)$. All procedures were carried out by 3 investigators of the Clinic of Animal Reproduction, Freie Universität Berlin, who had been trained according to the instructions of the manufacturer. One Precision Xtra meter was used for all BHBA measurements in experiment 1 .

In experiment 2, a multicenter study with 35 bovine veterinary practices was conducted. Samples were collected from a total of 926 dairy cows from 77 different farms (average 12 samples per farm). The participating practices were provided a package containing all necessary equipment and disposables (e.g., one electronic meter, test strips, prelabeled vacuum tubes, needles, prelabeled serum tubes, styrofoam containers, and cool packs for shipping). A manual explaining the procedure was also provided. The investigators were asked to select up to 3 farms at their discretion for sampling. Targets for sample size and lactational status were set at 10 to 15 cows per farm and 0 to $42 \mathrm{~d}$ in milk, 
respectively. Again, blood samples were drawn from the coccygeal vein and/or artery with vacuum tubes. Whole blood was transferred to the sensor of the test strip as described above. Concentrations of BHBA, cow identification, weeks after calving, and investigator information were recorded onto a data capture form and faxed to the Clinic of Animal Reproduction. Blood samples were centrifuged in the participating practices and serum was stored frozen until pick up and analysis. Serum samples were analyzed for BHBA photometrically in the same laboratory as in experiment 1 . One Precision Xtra meter was used per investigator for all BHBA measurements.

\section{Statistical Analyses}

Data were analyzed using SPSS for Windows (Version 15.0; SPSS Inc., Munich, Germany). Serum BHBA concentrations determined in the laboratory were regarded as the gold standard. In experiment 1, correlation coefficients (Pearson) were calculated between BHBA concentrations in serum measured in the laboratory and values displayed on the meter for whole blood, milk, and urine. Means and binomial 95\% confidence intervals $\left(\mathbf{C I}_{\mathbf{9 5}}\right)$ of test characteristics (sensitivity, specificity, and positive and negative predictive values) for the different cowside tests were calculated. Sensitivity was calculated as the proportion of cows with serum BHBA concentrations greater than or equal to $1,400 \mu \mathrm{mol} / \mathrm{L}$ correctly diagnosed as positive by the test. Specificity was calculated as the proportion of cows with serum BHBA concentrations less than 1,400 $\mu \mathrm{mol} / \mathrm{L}$ correctly diagnosed as negative by the test. The positive predictive value was calculated as the proportion of the animals with positive tests that were truly subclinically ketotic. The negative predictive value was calculated as the proportion of the animals with negative tests that were truly healthy. The predictive values calculated apply only to the apparent prevalences in the 2 study populations. In experiment 2 , correlation coefficients (Pearson) were calculated between BHBA concentrations in serum measured in the laboratory and values measured with the Precision Xtra test in whole blood. Test characteristics were calculated. Cows with BHBA concentrations greater or equal than $1,400 \mu \mathrm{mol} / \mathrm{L}$ of blood serum were classified as subclinically ketotic. Because a clinical measurement comparison using correlation coefficients can be inappropriate, agreement between the Precision Xtra test and the gold standard was analyzed graphically for both experiments using the method of Bland and Altman (1986). For each sample, the differences between the 2 tests were calculated and plotted against their mean. For the multicenter trial (experiment 2), the distributions of the differences between the 2 tests were shown as a boxplot for each investigator. Variances of the 2 tests were calculated using 3 BHBA classes: $<1,000,1,000-1,400$, and $>1,400$ $\mu \mathrm{mol}$ of $\mathrm{BHBA} / \mathrm{L}$ of blood.

\section{RESULTS}

\section{Experiment 1}

Of the 196 blood samples collected, 17 (8.7\%; $\mathrm{CI}_{95}$ $=5.1,13.5)$ contained $\geq 1,200 \mu \mathrm{mol}$ and $10(5.1 \%$; $\left.\mathrm{CI}_{95}=2.4,9.1\right)$ contained $\geq 1,400 \mu \mathrm{mol}$ of BHBA/L of blood. Coefficients of correlation for BHBA concentrations determined with different cowside tests and using different substrates compared with BHBA serum concentrations as the gold standard are summarized in Table 1. Pearson correlation coefficients were highly significant for all 5 cowside tests. The highest correlation coefficient (0.95) was calculated for BHBA concentration determined with the Precision Xtra meter in whole blood. Correlation coefficients for Precision Xtra and Ketostix both used with urine and Ketolac were comparable but lower. Test characteristics of all cowside tests considering different thresholds are reported in Table 2. The Precision Xtra test was both highly sensitive and specific at 1,400 $\mu \mathrm{mol}$ of BHBA/L of whole blood. When the Precision Xtra test was used with milk or urine sensitivity and specificity decreased considerably. Ketostix and Ketolac were highly sensitive at $\leq 4,000 \mu \mathrm{mol}$ of BHBA/L of urine and at $100 \mu \mathrm{mol}$ of $\mathrm{BHBA} / \mathrm{L}$ of milk, respectively. Specificity of the 2 chemical tests was highest at $\geq 4,000 \mu \mathrm{mol}$ of BHBA/L of urine and $200 \mu \mathrm{mol}$ of BHBA/L of milk. A summary of parameters regarding the level of agreement between the 2 tests is given in Table 3 . The hand-held meter gave lower readings than the serum BHBA $(-32.4 \pm$ $152.7 \mu \mathrm{mol}$ of BHBA/L of blood, $P<0.05)$.

\section{Experiment 2}

On average, 27 samples per investigator and 12 samples per farm were collected. Of all cows enrolled, $81.7 \%$ were between calving and 42 DIM. Some samples were drawn from dry cows $(\mathrm{n}=106 ; 11.4 \%)$ and from cows with unknown lactational status $(\mathrm{n}=64 ; 6.9 \%)$. In the multicenter trial, the overall proportion of serum BHBA concentrations of $\geq 1,200$ and $\geq 1,400 \mu \mathrm{mol} / \mathrm{L}$ was $15.7 \%\left(\mathrm{CI}_{95}=13.4-18.2 \%\right)$ and $11.0 \%\left(\mathrm{CI}_{95}=\right.$ $9.1-13.2 \%)$, respectively $(\mathrm{n}=926)$. Coefficients of correlation for BHBA concentrations determined in serum and in whole blood with the Precision Xtra test was 0.94 (Figure $1 ; \mathrm{r}^{2}=0.88, P<0.001$ ). The Precision Xtra test at 1,200 and 1,400 $\mu \mathrm{mol}$ of $\mathrm{BHBA} / \mathrm{L}$ of whole blood had sensitivities of $88\left(\mathrm{CI}_{95}=82-93 \%\right)$ and $96 \%$ 
Table 1. Pearson correlation coefficients for concentrations of BHBA determined with different cowside tests and in different substrates compared with BHBA serum concentrations as the gold standard (experiment 1)

\begin{tabular}{llccc}
\hline Test $^{1}$ & Substrate & Tests $(\mathrm{n})^{2}$ & $\begin{array}{c}\text { Pearson } \\
\text { correlation }\end{array}$ & $\begin{array}{c}\text { Level of } \\
\text { significance }\end{array}$ \\
\hline Precision Xtra & Whole blood & 196 & 0.95 & $P<0.001$ \\
Precision Xtra & Milk & 194 & 0.53 & $P<0.001$ \\
Precision Xtra & Urine & 186 & 0.66 & $P<0.001$ \\
Ketostix & Urine & 186 & 0.64 & $P<0.001$ \\
Ketolac & Milk & 194 & 0.63 & $P<0.001$ \\
\hline
\end{tabular}

${ }^{1}$ Precision Xtra from Abbott Diabetes Care (Abingdon, UK); Ketostix from Bayer (Leverkusen, Germany); and Ketolac from Biolab (München, Germany).

${ }^{2}$ Number of observations paired with a serum BHBA measurement for each cowside test.

$\left(\mathrm{CI}_{95}=95-98 \%\right)$, respectively. Specificities for the 2 thresholds were $96\left(\mathrm{CI}_{95}=95-98 \%\right)$ and $97 \%\left(\mathrm{CI}_{95}=\right.$ 96-98\%), respectively. Positive predictive values were $82 \%\left(\mathrm{CI}_{95}=75-87 \% ; 74-89 \%\right)$ for both thresholds while negative predictive values were $98\left(\mathrm{CI}_{95}=96-99 \%\right)$ and $100 \%\left(\mathrm{CI}_{95}=99-100 \%\right)$ for 1,200 and $1,400 \mu \mathrm{mol}$ of BHBA/L of whole blood, respectively (Table 3). Again, the hand-held meter gave lower readings than the serum BHBA $(-48.2 \pm 261.7 \mu \mathrm{mol} / \mathrm{L}, P<0.001)$. Plotting the differences of BHBA measured with the Precision Xtra test and the gold standard against their mean revealed a higher agreement of the 2 tests in experiment 1 compared with experiment 2 (Figure 2). Overall variance of the 2 tests was considerably higher $(9.7 \%)$ in experiment 2 compared with experiment $1(4.2 \%)$. The percentage of samples with a variance $>20 \%$ was $1.5 \%$ and $19.0 \%$ in experiments 1 and 2, respectively; however, the proportion of samples with a variance $>20 \%$ did not increase with increasing BHBA class (Table 4).
For the majority of investigators variance between the 2 tests was relatively small (Figure 3 ).

\section{DISCUSSION}

The overall proportion of serum BHBA concentrations of $\geq 1,400 \mu \mathrm{mol} / \mathrm{L}$ was 5.1 and $11.0 \%$ for experiments 1 and 2, respectively. A direct comparison with prevalence rates from previous studies using the same threshold (7.6\%, Carrier et al., 2004; and 12.0\%, Geishauser et al., 2000) is critical because these studies used convenience samples as well. Furthermore, important variables such as median days in milk and milk production differed or were not described.

Because the investigators in experiment 2 were asked to select up to 3 sites at their own discretion (i.e., convenience sample), a preselection toward farms with a higher prevalence of metabolic disorders probably occurred. It is likely that this selection process contrib-

Table 2. Performance of 3 cowside diagnostic tests for detection of subclinical ketosis defined as BHBA serum concentrations $\geq 1,400 \mu$ mol/L (experiment 1$)^{1}$

\begin{tabular}{|c|c|c|c|c|c|c|c|}
\hline Test $^{2}$ & Substrate & $\begin{array}{l}\text { Threshold } \\
(\mu \mathrm{mol} / \mathrm{L})\end{array}$ & Tests $(\mathrm{n})^{3}$ & $\begin{array}{l}\text { Se }(\%) \\
\left(\mathrm{CI}_{95}\right)\end{array}$ & $\begin{array}{c}\mathrm{Sp}(\%) \\
\left(\mathrm{CI}_{95}\right)\end{array}$ & $\begin{array}{c}+\mathrm{PV}(\%) \\
\quad\left(\mathrm{CI}_{95}\right)\end{array}$ & $\begin{array}{c}-\mathrm{PV}(\%) \\
\left(\mathrm{CI}_{95}\right)\end{array}$ \\
\hline Precision Xtra & Whole blood & 1,400 & 196 & $100(69-100)$ & $100(94-100)$ & $100(69-100)$ & $100(98-100)$ \\
\hline Precision Xtra & Milk & 200 & 194 & $60(26-88)$ & $89(83-93)$ & $22(9-42)$ & $98(94-99)$ \\
\hline Ketolac & Milk & 100 & 194 & $90(56-100)$ & $94(90-97)$ & $45(23-68)$ & $99(97-100)$ \\
\hline Ketolac & Milk & 200 & 194 & $30(7-65)$ & $98(95-100)$ & $50(12-88)$ & $96(93-99)$ \\
\hline Precision Xtra & Urine & 1,000 & 186 & $100(66-100)$ & $25(19-32)$ & $6(3-14)$ & $100(92-100)$ \\
\hline Ketostix & Urine & 1,500 & 186 & $67(30-93)$ & $97(94-99)$ & $36(23-83)$ & $100(95-100)$ \\
\hline Ketostix & Urine & 4,000 & 186 & $67(30-93)$ & $100(98-100)$ & $100(54-100)$ & $98(95-100)$ \\
\hline Ketostix & Urine & 8,000 & 186 & $44(14-79)$ & $100(98-100)$ & $100(40-100)$ & $97(94-99)$ \\
\hline Ketostix & Urine & 16,000 & 186 & $22(3-60)$ & $100(98-100)$ & $100(16-100)$ & $98(92-98)$ \\
\hline
\end{tabular}

${ }^{1} \mathrm{Se}=$ sensitivity: proportion of diseased cows that test positive; $\mathrm{Sp}=$ specificity: proportion of nondiseased cows that test negative; $+\mathrm{PV}=$ positive predictive value: proportion of cows with a positive test that are diseased; $-\mathrm{PV}=$ negative predictive value: proportion of cows with a negative test that are not diseased; $\mathrm{CI}_{95}=95 \%$ confidence interval.

${ }^{2}$ Precision Xtra from Abbott Diabetes Care (Abingdon, UK); Ketostix from Bayer (Leverkusen, Germany); and Ketolac from Biolab (München, Germany).

${ }^{3}$ Number of observations paired with a serum BHBA measurement for each cowside test. 
Table 3. Differences of Precision Xtra test compared with serum BHBA concentrations in both experiments

\begin{tabular}{lcc}
\hline Parameter & Experiment 1 & Experiment 2 \\
\hline Number of samples & 196 & 926 \\
Mean \pm SD $(\mu$ mol/L) & & \\
Precision Xtra & $723.0 \pm 468.4$ & $836.1 \pm 742.3$ \\
Serum BHBA & $755.4 \pm 474.9$ & $884.3 \pm 732.0$ \\
Difference mean \pm SD $(\mu \mathrm{mol} / \mathrm{L})$ & $32.4 \pm 152.7$ & $48.2 \pm 261.7$ \\
Variance $(\%)^{1}$ & 4.2 & 9.7 \\
Percentage of pairs with & 76.0 & 51.4 \\
variance $<10 \%$ & 98.5 & 81.0 \\
variance $<20 \%$ & 1.5 & 19.0 \\
variance $\geq 20 \%$ &
\end{tabular}

${ }^{1}$ Based on mean of serum BHBA and Precision Xtra test. Precision Xtra from Abbott Diabetes Care (Abingdon, UK).

uted to the higher overall prevalence of subclinically ketotic cows in experiment 2. There were differences in the diagnostic performance of the Ketostix and Ketolac tests compared with previous reports. Considering almost identical thresholds (i.e., 490, 1,470, 3,920, 7,840 , and $15,700 \mu \mathrm{mol}$ of $\mathrm{AcAc} / \mathrm{L}$ of urine), much lower sensitivities $(90,78,49,12,4 \%)$ have been reported for the Ketostix test, whereas specificities (90 to $100 \%$ ) were similar to ours (Carrier et al., 2004). At the same threshold (i.e., $100 \mu \mathrm{mol}$ of BHBA/L of milk) lower sensitivity (80\%) and specificity (76\%) have been described for the Ketolac test (Geishauser et al., 2000) compared with our data. At $200 \mu \mathrm{mol}$ of BHBA/L of milk, the sensitivity in this study was considerably lower than the $59 \%$ reported in the cited study. Reasons for these differences are unclear. Differences may be caused by variation in sampling or in interpreting the color changes of the test strips (Carrier et al., 2004). Moreover, it has been demonstrated that high milk SCC and feeding malfermented silage may inflate the results of milk ketone tests. Discrepancies between reports show that cowside tests based on color change may be prone to subjective interpretation and are difficult to standardize (Carrier et al., 2004).

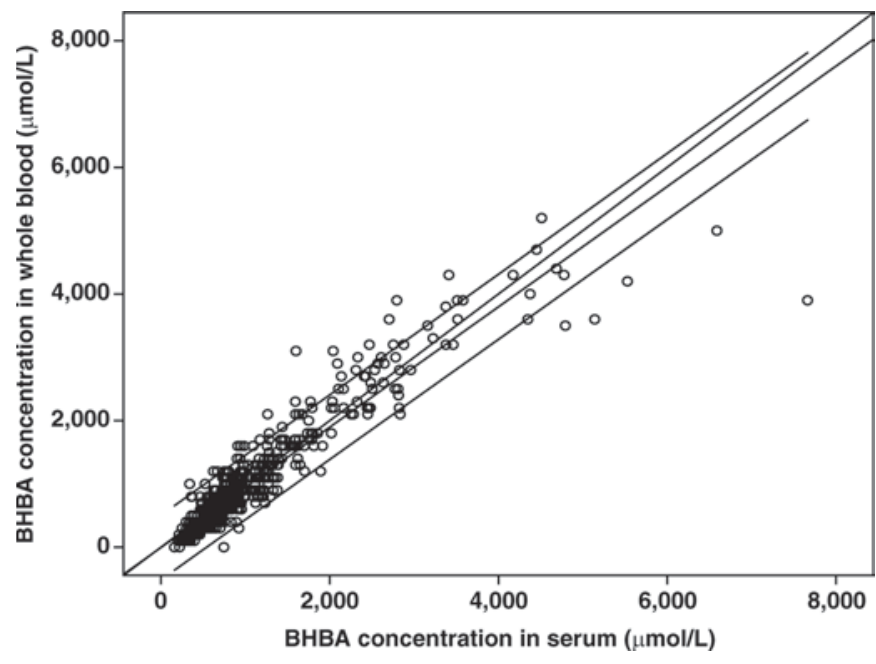

Figure 1. Correlation of BHBA measurement determined in serum (automated wet chemistry analyzer) and in whole blood (Precision Xtra test; Abbott Diabetes Care, Abingdon, UK) in experiment $2\left(\mathrm{r}^{2}\right.$ $=0.88, \mathrm{n}=926, P<0.001)$.

This is the first study validating an electronic handheld ketone measuring test to identify subclinical ketosis in dairy cows postpartum. Similarly strong correlations between serum BHBA and whole blood concentrations measured with the Precision Xtra test have been reported previously (Jeppesen et al., 2006; Heuwieser et al., 2007). Previous studies have also used the Precision Xtra test under varying conditions and demonstrated its usefulness in the field (Endecott et al., 2004; Bryk-Lucy et al., 2008) even though the strength of relationship or the level of agreement with a gold standard was not examined. A detailed evaluation of test characteristics of the Precision Xtra test has not yet been published. Using a cutoff BHBA concentration of $\geq 1,400 \mu \mathrm{mol}$ of $\mathrm{BHBA} / \mathrm{L}$ of whole blood, the Precision Xtra test achieved the highest sensitivity and specificity of all tests in experiment 1. Data from the first experiment clearly demonstrate that the Precision Xtra test has a

Table 4. Variance between Precision Xtra test and serum BHBA considering 3 ranges of BHBA concentrations in experiment 2

\begin{tabular}{|c|c|c|c|c|c|c|c|c|}
\hline \multirow{3}{*}{$\begin{array}{l}\text { Pairs with } \\
\text { variance }^{1}\end{array}$} & \multicolumn{6}{|c|}{ Class of BHBA concentration $(\mu \mathrm{mol} / \mathrm{L})$} & & \\
\hline & \multicolumn{2}{|c|}{$<1,000$} & \multicolumn{2}{|c|}{$1,000-1,400$} & \multicolumn{2}{|c|}{$>1,400$} & \multicolumn{2}{|c|}{ Total } \\
\hline & $\mathrm{n}$ & $\%$ & $\mathrm{n}$ & $\%$ & $\mathrm{n}$ & $\%$ & $\mathrm{n}$ & $\%$ \\
\hline$<5 \%$ & 200 & 27.3 & 32 & 37.6 & 43 & 39.8 & 275 & 29.7 \\
\hline$\leq 10 \%$ & 150 & 20.5 & 19 & 22.4 & 33 & 30.6 & 202 & 21.8 \\
\hline$\leq 20 \%$ & 219 & 29.9 & 27 & 31.8 & 27 & 25.0 & 273 & 29.5 \\
\hline$>20 \%$ & 164 & 22.4 & 7 & 8.2 & 5 & 4.6 & 176 & 19.0 \\
\hline Total & 733 & 100.0 & 85 & 100.0 & 108 & 100.0 & 926 & 100.0 \\
\hline
\end{tabular}

${ }^{1}$ Based on mean of serum BHBA and Precision Xtra test. Precision Xtra from Abbott Diabetes Care (Abingdon, UK). 

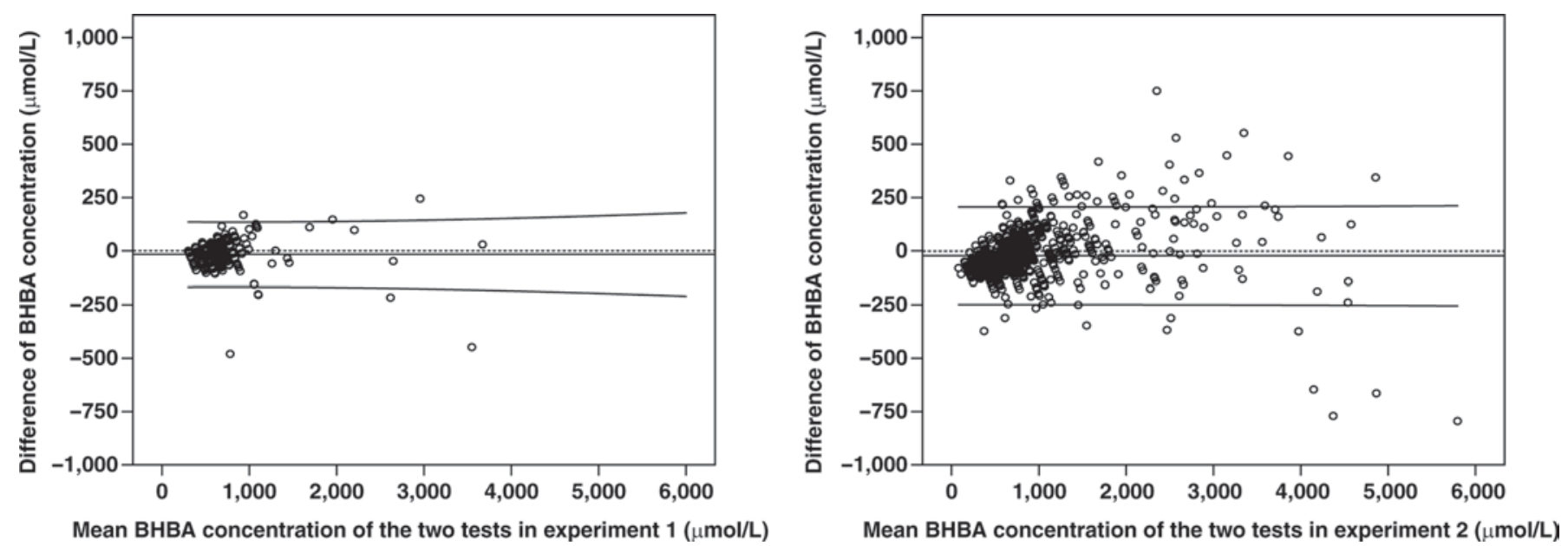

Figure 2. Differences of BHBA concentrations measured with Precision Xtra test (Abbott Diabetes Care, Abingdon, UK) and the gold standard against their mean (in $\mu \mathrm{mol} / \mathrm{L}$ ) for experiments 1 (left) and 2 (right).

better diagnostic performance than the 2 semiquantitative chemical cowside tests and that using whole blood as substrate yields higher accuracy compared with urine and milk. Also, the Precision Xtra test is not subjective, because results are displayed digitally.

In the second experiment involving 35 investigators and 77 sites, the test performance was also high (96\% sensitivity, $97 \%$ specificity). However, level of agreement between the Precision Xtra test and the gold standard was lower in experiment 2 compared with ex- periment 1 (Figure 2; Table 3). This observation could be due to the fact that 3 equally trained investigators of the Clinic of Animal Reproduction conducted all procedures in the first experiment in close accordance to a standard operating procedure. In experiment 2, however, the investigators $(\mathrm{n}=35)$ had only received a brief manual describing the procedures. For logistical reasons, a standardized training was not performed. From Figure 3, it is apparent that most of the investigators achieved high levels of agreement between the 2

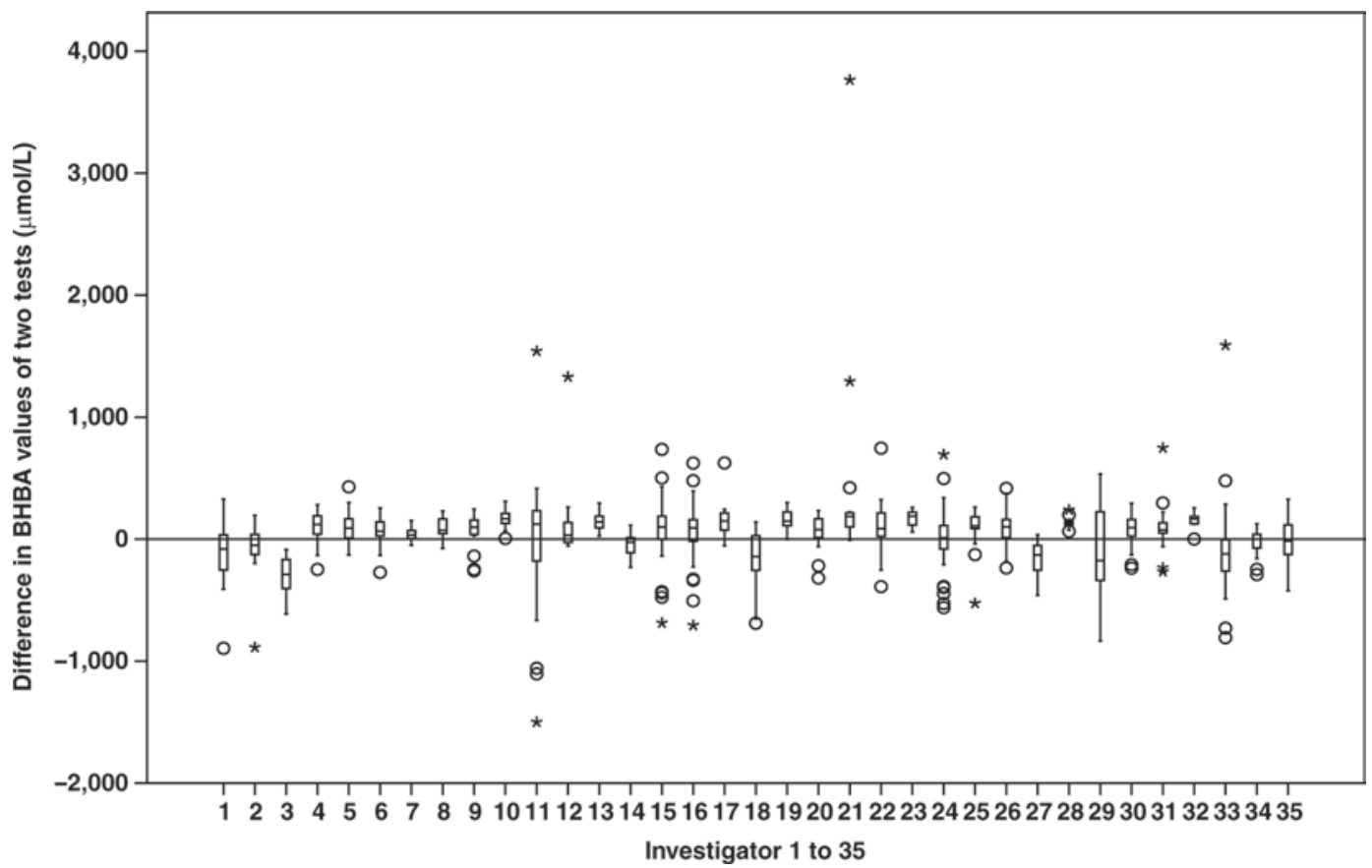

Figure 3. Boxplots of differences between BHBA concentrations measured with the Precision Xtra test (Abbott Diabetes Care, Abingdon, UK) in whole blood and the gold standard for 35 investigators (experiment 2). Circles indicate outliers (1.5 to 3.0 interquartile range); asterisks indicate extreme outliers ( $>3.0$ interquartile range). 
tests while others (e.g., numbers 11 and 29) had poor agreement. It can be speculated that inconsistencies in collecting the samples and processing the blood caused these high variances. It remains unclear whether the relatively low level of agreement between the 2 tests achieved by those investigators was caused by erroneously using the Precision Xtra test or by processing the blood for serum collection differently from the descriptions in the manual or inconsistently, thus confounding the results. The proportion of samples indicative of subclinical ketosis (i.e., $\geq 1,400 \mu \mathrm{mol}$ of BHBA/L of blood) varied widely among investigators, probably because of a different selection of herds. However, the proportion of samples with a variance $>20 \%$ did not increase with increasing BHBA concentrations. Further research is needed to identify the factors that can affect the measurement of BHBA concentrations in the laboratory and with the Precision Xtra test.

\section{CONCLUSIONS}

The Precision Xtra test is a useful cowside ketone test for detection of subclinical ketosis in postpartum dairy cows. Using whole blood and a cutoff value of $\geq 1,400 \mu \mathrm{mol}$ of BHBA/L of blood, the Precision Xtra test achieved excellent test characteristics and a higher diagnostic performance than 2 chemical dipsticks. Further research is required to evaluate the effects of pre- and intra-analytical factors that might influence test results. Sensitivity and specificity of the Precision Xtra test was considerably lower in milk or urine. Considering the ease of sampling, however, it should be investigated to determine if diagnostic performance of the Precision Xtra test using milk as a substrate can be improved.

\section{ACKNOWLEDGMENTS}

The authors gratefully acknowledge the cooperation with the staff of 35 veterinary practices and 77 dairy farms in Germany.

\section{REFERENCES}

Andersson, L. 1988. Subclinical ketosis in dairy cows. Metabolic diseases of ruminant livestock. Vet. Clin. North Am. Food Anim. Pract. 4:233-251.

Bland, J. M., and D. G. Altman. 1986. Statistical methods for assessing agreement between two methods of clinical measurement. Lancet 338:307-310.

Bryk-Lucy, J., D. Nydam, A. Delgado Castro, A. Gonzales Zariquiey, and M. Montenegro Vega. 2008. Prevalence of subclinical metabolic disease in transition dairy cows on large dairies in Peru. Hungarian Vet. J. 130(Suppl. 2):72.

Carrier, J., S. Stewart, S. Godden, J. Fetrow, and P. Rapnicki. 2004. Evaluation and use of three cowside tests for detection of subclinical ketosis in early postpartum cows. J. Dairy Sci. 87:3725-3735.

Duffield, T. F. 1997. Effects of a monensin controlled release capsule on energy metabolism, health, and production in lactating dairy cattle. DVSc Thesis. University of Guelph, Ontario, Canada.

Duffield, T. F. 2000. Subclinical ketosis in lactating dairy cattle: Metabolic disorders of ruminants. Vet. Clin. North Am. Food Anim. Pract. 16:231-253.

Endecott, R.L., C. M. Black, K. A. Notah, and M. K. Petersen. 2004 Blood ketone levels of young postpartum range cows increased after supplementation ceased. J. Anim. Sci. 82(Suppl. 1):114.

Geishauser, T., K. Leslie, D. Kelton, and T. Duffield. 1998. Evaluation of five cowside tests for use with milk to detect subclinical ketosis in dairy cows. J. Dairy Sci. 81:438-443.

Geishauser, T., K. Leslie, D. Kelton, and T. Duffield. 2001. Monitoring for subclinical ketosis in dairy herds. Compend. Contin. Educ. Pract. Vet. 23:65-71.

Geishauser, T., K. Leslie, J. Tenhag, and A. Bashiri. 2000. Evaluation of eight cow-side ketone tests in milk for detection of subclinical ketosis in dairy cows. J. Dairy Sci. 83:296-299.

Guerci, B., N. Tubiana-Rufi, B. Bauduceau, R. Bresson, A. Cuperlier, C. Delcroix, D. Durain, C. Fermon, J. P. Le Floch, C. LeDevehat, V. Melki, L. Monnier, H. Mosnier-Pudar, P. Taboulet, and H. Hanaire-Broutin. 2005. Advantages to using capillary blood betahydroxybutyrate determination for the detection and treatment of diabetic ketosis. Diabete Metab. 31:401-440.

Heuwieser, W., U. Falkenberg, M. Iwersen, R. Voigtsberger, and W. Padberg. 2007. Evaluation and use of an automated human $\beta$-hydroxybuturate (BHBA) test for cowside detection of subclinical ketosis in dairy cattle. Page 253 in Proc. 40th Annu. Conv. Am. Assoc. Bov. Pract., Vancouver, BC. Am. Assoc. Bov. Pract., Stillwater, OK.

Jeppesen, R., J. M. D. Enemark, and C. Enevoldsen. 2006. Ketone body measurement in dairy cows. Reference OS43-2 in Proc. 24th World Buiatrics Congress, Nice, France. World Assoc. Buiatrics, Vienna, Austria.

Oetzel, G. R. 2004. Monitoring and testing dairy herds for metabolic disease. Vet. Clin. North Am. Food Anim. Pract. 20:651-674.

Stokol, T., and D. V. Nydam. 2005. Effect of anticoagulant and storage conditions on bovine nonesterified fatty acids and $\beta$-hydroxybuturate concentrations in blood. J. Dairy Sci. 88:3139-3144. 